\title{
Identity and Pathogenicity of Two Phytophthora Taxa Associated with a New Root Disease of Olive Trees
}

Esperanza Sánchez-Hernández and Mónica Muñoz-García, Dep. Agronomía, ETSIAM, Universidad de Córdoba, Apdo. 3048, 14080 Córdoba, Spain; Clive M. Brasier, Forestry Commission Research Agency, Alice Holt Lodge, Farnham, Surrey GU10 4LH, UK; and Antonio Trapero-Casas, Dep. Agronomía, ETSIAM, Universidad de Córdoba, Apdo. 3048, 14080

\begin{abstract}
Sánchez-Hernández, E., Muñoz-García, M., Brasier, C. M., and Trapero-Casas, A. 2001. Identity and pathogenicity of two Phytophthora taxa associated with a new root disease of olive trees. Plant Dis. 85:411-416.

Fifty-two Phytophthora isolates from necrotic roots of olives were characterized. Colony morphologies on carrot-agar medium led us to separate them into two groups: A (36 isolates) and B (16 isolates). The optimum growth temperature for Group A was about $21^{\circ} \mathrm{C}$, with slow growth at $30^{\circ} \mathrm{C}$. In contrast, Group B isolates had an optimum temperature for growth of $26^{\circ} \mathrm{C}$, and grew rapidly at $30^{\circ} \mathrm{C}$. Growth rates, sporangial and oogonial characteristics of the Group A isolates conformed to P. megasperma "BHR-type" sensu stricto. This designation was supported by a sequence analysis of their ITS rDNA regions. Colony patterns, sporangial characteristics and temperature-growth relationships of the Group B isolates conformed closely to those of the ' $\mathrm{O}$ group' taxon of Phytophthora. They also conformed to this unusual taxon in their ITS sequence. In addition, Group B isolates were either entirely self-sterile, self-sterile A1s or weakly selffertile. Pathogenicity tests showed that both taxa were highly aggressive on roots of olive trees. The association of flooding with Phytophthora infection indicates that the previously reported high sensitivity of olive to root asphyxiation may be more properly regarded as root-rot caused by Phytophthora spp.
\end{abstract}

In recent years a wilt and death of young olive trees of unknown etiology has been observed on new olive (Olea europaea) plantations in southern Spain. Death of trees occurs rapidly, with or without previous yellowing or defoliation. The syndrome has been called "seca" (drying) to distinguish it from other diseases, such as Verticillium wilt or insect damage, that can induce similar symptoms (19).

In field surveys carried out in 1996, most of the affected plantations had waterlogged or very wet soils. In all of these plantations, death was associated with root rot. Fungal isolations from the affected roots consistently yielded Phytophthora spp. (94\% of the plantations showing root rot). The same problem was observed in older plantations, but trees were not severely affected (19).

Several species of Phytophthora, including $P$. citricola and $P$. drechsleri, have been associated with root and crown rot of olive trees in California (22). In Greece, Kouyeas and Chitzanidis (15) reported $P$. megasperma as an olive tree pathogen.

Corresponding author: Antonio Trapero-Casas E-mail: trapero@uco.es

Accepted for publication 12 December 2000.

Publication no. D-2001-0212-01R

(c) 2001 The American Phytopathological Society
Other non-identified Phytophthora spp. have been associated with root rot of olive trees $(11,25)$. High soil water content and low oxygen content favor root rots caused by Phytophthora species on woody hosts such as orange trees, avocado, apple trees, and others $(6,10,21)$. Traditionally, olive trees have been considered very susceptible to "root asphyxiation" associated with waterlogging. The aim of the present work was to clarify the role of the Phytophthora spp. in olive "seca" through the characterization of isolates obtained from symptomatic roots of olive.

\section{MATERIALS AND METHODS}

Fifty-two Phytophthora isolates were obtained from necrotic roots of young olive trees sampled in 1996 in southern Spain (Provinces of Córdoba, Jaén, and Sevilla) (Table 1).

Morphology of the colonies and growth-rate tests. Two different culture media were used to characterize colony morphology: Corn-meal Agar (CMA), a general purpose medium (8); and Carrot Agar (CA) for assessing colony characteristics and oogonial production $(4,10)$. Agar plugs $7-\mathrm{mm}$ in diameter were cut from edges of actively growing colonies, placed in the center of Petri dishes (9-cm diameter, 20-ml media/plate), and incubated in darkness. For each isolate, three replicates per culture medium and temperature were prepared. Temperatures used were 5, 10,
$15,20,25$, and $30^{\circ} \mathrm{C}$. Colony diameters were measured after 4, 6, 10, and 15 days.

Colony morphology was assessed after 4 or 6 days growth at $20^{\circ} \mathrm{C}$. Growth-rates per day were calculated for the different media and temperatures and maximum average data were adjusted to a regression curve. Adjustment was made using Statistix for Windows (Analytical Software, Tallahassee, FL). The best polynomial model was chosen from several combinations of terms, based on the significance of the estimated parameters $(P \leq 0.05)$, coefficients of determination $\left(R^{2}\right)$, coefficients of determination adjusted for degrees of freedom $\left(R_{a}^{2}\right)$, and pattern of residuals (9). The optimum growth temperature was estimated for each isolate tested.

Sporangial morphology. Twenty-five isolates from different location were selected and grown individually on CA medium for 7 days in darkness at $20^{\circ} \mathrm{C}$. Ninemm-diameter agar plugs from these plates were placed in 5-cm-diameter Petri dishes and soil extract was added to just cover the plugs. Soil extract was prepared by mixing $10 \mathrm{~g}$ of soil from olive tree rhizosphere and 1 liter distilled water, standing for $24 \mathrm{~h}$ at $20^{\circ} \mathrm{C}$ and filtering through filter paper. Petri dishes then were incubated in darkness at $15^{\circ} \mathrm{C}$. Every $24 \mathrm{~h}$, the soil extract was removed and replaced with fresh extract that had been stored at $4^{\circ} \mathrm{C}$. Sporangial production was assessed by direct observation using an inverted microscope. Sporangial development occurred between 12 and $120 \mathrm{~h}$. Mature sporangia were removed and placed on glass microscope slides, then stained with acid fuchsin in lactophenol. The length and width of 25 sporangia per isolate were measured. Analysis of variance was performed and mean values were compared by Fisher's protected least significant difference (LSD) test (20). Other sporangial characteristics such as shape, presence or absence of papilla, persistence, proliferation, and branching of sporangiophores, were also recorded.

Sexual behavior. The 25 Phytophthora isolates (Table 1) were grown on CA medium at $20^{\circ} \mathrm{C}$ in darkness. In some cases, after 7 to 10 days of growth, sexual reproductive structures were present. Samples of these were moved to slides and stained with acid fuchsin in lactophenol, and oogonial and oospore diameter, antheridial 
length, and oospore cell wall thickness were measured for 25 randomly selected mature oogonia.

When no oogonia were present in single culture after 15 days growth, pairing tests were carried out with A1 and A2 compatibility type isolates of $P$. drechsleri (P537 and P540; Phytophthora Culture Collection, Forestry Commission Research Agency, Farnham, UK). P. drechsleri has proved an effective test organism for assaying sterility and unusual compatibility reactions in other Phytophthora species, such as $P$. gonapodyides (5). Pairings were replicated three times on $\mathrm{CA}$ medium and incubated for 15 days at $20^{\circ} \mathrm{C}$ in the dark. When oogonia formed, scrapings were taken from the colony interface and mounted and stained as above.

Pathogenicity tests. Eight Phytophthora isolates from olive, representing groups A and B established here, were used; three Phytophthora isolates from other hosts in southern Spain and in California (Table 1): $P$. megasperma sensu stricto (isolate PM007 from peach tree); $P$. medicaginis sp. nov. (isolate PM004 from alfalfa); and $P$. ciceris sp. nov. (isolate PM033 from

Table 1. Origin and colony patterns of the isolates of Phytophthora studied

\begin{tabular}{|c|c|c|c|c|}
\hline Isolate & Location & Date of isolation & Host/cultivar & Colony pattern ${ }^{y}$ \\
\hline $\mathrm{PO}^{*} * \mathrm{z}$ & La Conchuela, Córdoba & March 1996 & Olive 'Arbequino' & A \\
\hline PO4* & La Conchuela, Córdoba & March 1996 & Olive 'Arbequino' & A \\
\hline PO5 & El Saucejo, Sevilla & March 1996 & Olive 'Arbequino' & A \\
\hline PO6 & El Saucejo, Sevilla & March 1996 & Olive 'Picual' & A \\
\hline PO8* & El Saucejo, Sevilla & March 1996 & Olive 'Picual' & B \\
\hline PO10* & El Saucejo, Sevilla & March 1996 & Olive 'Hojiblanco' & A \\
\hline PO11 & Lucena, Córdoba & April 1996 & Olive 'Picual' & A \\
\hline PO12* & Lucena, Córdoba & April 1996 & Olive 'Picual' & A \\
\hline $\mathrm{PO} 13$ & Lucena, Córdoba & April 1996 & Olive 'Picual' & A \\
\hline PO15* & Ecija, Sevilla & April 1996 & Olive 'Picual' & B \\
\hline PO16* & Guillena, Sevilla & April 1996 & Olive 'Picual' & B \\
\hline PO18 & Porcuna, Jaén & May 1996 & Olive 'Picual' & A \\
\hline PO19 & Ecija, Sevilla & April 1996 & Olive 'Picual' & A \\
\hline PO20* & La Carlota, Córdoba & April 1996 & Olive 'Arbequino' & A \\
\hline $\mathrm{PO} 23$ & Castro del Río, Córdoba & April 1996 & Olive 'Picual' & A \\
\hline $\mathrm{PO} 24$ & Castro del Río, Córdoba & April 1996 & Olive 'Picual' & A \\
\hline PO25 & Castro del Río, Córdoba & April 1996 & Olive 'Picual' & A \\
\hline PO26* & Castro del Río, Córdoba & April 1996 & Olive 'Picual' & A \\
\hline $\mathrm{PO} 27 *$ & Castro del Río, Córdoba & April 1996 & Olive 'Picual' & B \\
\hline $\mathrm{PO} 28^{*}$ & Castro del Río, Córdoba & April 1996 & Olive 'Picual' & B \\
\hline PO29 & Castro del Río, Córdoba & April 1996 & Olive 'Picual' & A \\
\hline PO30 & Castro del Río, Córdoba & April 1996 & Olive 'Picual' & A \\
\hline PO34* & Vilches, Jaén & June 1996 & Olive 'Picual' & $\mathrm{B}$ \\
\hline PO35* & Vilches, Jaén & June 1996 & Olive 'Picual' & B \\
\hline PO36 & Vilches, Jaén & June 1996 & Olive 'Picual' & B \\
\hline PO37* & Vilches, Jaén & June 1996 & Olive 'Picual' & A \\
\hline PO38* & Vilches, Jaén & June 1996 & Olive 'Picual' & B \\
\hline $\mathrm{PO} 39 *$ & Vilches, Jaén & June 1996 & Olive 'Picual' & B \\
\hline $\mathrm{PO} 40 *$ & Vilches, Jaén & June 1996 & Olive 'Picual' & A \\
\hline PO41 & El Mármol, Jaén & June 1996 & Olive 'Picual' & A \\
\hline $\mathrm{PO} 42 *$ & Espejo, Córdoba & June 1996 & Olive 'Arbequino' & A \\
\hline $\mathrm{PO} 43$ & Espejo, Córdoba & June 1996 & Olive ‘Arbequino’ & A \\
\hline PO45 & Espejo, Córdoba & June 1996 & Olive 'Arbequino' & A \\
\hline $\mathrm{PO} 47 *$ & Castro del Río, Córdoba & June 1996 & Olive 'Picual' & B \\
\hline PO48 & Castro del Río, Córdoba & June 1996 & Olive 'Picual' & B \\
\hline PO49 & Ubeda, Jaén & June 1996 & Olive 'Picual' & A \\
\hline PO50* & Fuente del Rey, Jaén & June 1996 & Olive 'Picual' & B \\
\hline PO51 & Castro del Río, Córdoba & June 1996 & Olive 'Picual' & A \\
\hline PO52 & Beas de Segura, Jaén & June 1996 & Olive 'Picual' & A \\
\hline PO53* & Torres de Albanchez, Jaén & June 1996 & Olive 'Picual' & A \\
\hline PO54 & La Puerta de Segura, Jaén & June 1996 & Olive 'Picual' & B \\
\hline PO55* & La Puerta de Segura, Jaén & June 1996 & Olive 'Picual' & B \\
\hline PO56* & Morón, Sevilla & June 1996 & Olive 'Manzanillo' & A \\
\hline PO59 & La Luisiana, Sevilla & June 1996 & Olive ‘Arbequino’ & A \\
\hline PO61 & Cañada del Rosal, Sevilla & June 1996 & Olive 'Picual' & A \\
\hline PO62* & La Luisiana, Sevilla & June 1996 & Olive ‘Arbequino' & B \\
\hline PO63* & La Luisiana, Sevilla & June 1996 & Olive 'Arbequino' & A \\
\hline PO64 & Doña Mencía, Córdoba & July 1996 & Olive 'Picual' & A \\
\hline PO65 & Doña Mencía, Córdoba & July 1996 & Olive 'Picual' & A \\
\hline PO66 & Cabra, Córdoba & July 1996 & Olive 'Picual' & A \\
\hline PO67 & Priego, Córdoba & July 1996 & Olive 'Picual' & A \\
\hline PO68 & Priego, Córdoba & July 1996 & Olive 'Picual' & A \\
\hline PM004 & California, USA & 1989 & Alfalfa & - \\
\hline PM007 & Sevilla & 1989 & Peach tree & - \\
\hline PM033 & Castro-Cañete, Córdoba & 1990 & Chickpea & - \\
\hline
\end{tabular}

${ }^{\mathrm{y}}$ Colony pattern for isolates from olive trees on carrot agar medium: $\mathrm{A}=$ flat to slightly petaloid, $\mathrm{B}=$ "rosette."

$\mathrm{z} *=$ Isolates used for growth tests and morphological characterization.

chickpea) (18) were used for comparison. These last three isolates were previously assigned to $P$. megasperma sensu lato.

Plant material was obtained from a commercial nursery, and consisted of young rooted cuttings ( 6 to 12 months old, cv. Picual). Inocula were prepared by modifying the method of Wilcox and Mircetich (24). For each isolate, one inoculum flask was prepared by mixing $250 \mathrm{ml}$ vermiculite and $20 \mathrm{ml}$ autoclaved oat seeds, with $150 \mathrm{ml}$ carrot broth. Each flask was inoculated with one isolate and incubated at $20^{\circ} \mathrm{C}$ in darkness for 30 days, stirring every 3 to 4 days. To prepare infested soil, the contents of each flask were mixed separately with 12 liters of previously autoclaved soil (sand:lime:peat, 1:1:1) (23), resulting in a concentration of $35 \mathrm{ml}$ inoculum per liter of soil.

Roots were carefully cleaned under tap water before the plants were transferred into plastic pots containing 2 liters of infested soil. Six replicates of each isolate were gathered in one plastic tray to avoid cross contamination and placed in a growth chamber $\left(228 \varnothing \mathrm{E} / \mathrm{cm}^{2} \mathrm{~s}\right.$ light, $14 \mathrm{~h} / \mathrm{day}, 24^{\circ} \mathrm{C}$ maximum mean temperature, $19^{\circ} \mathrm{C}$ minimum mean temperature, $87 \%$ maximum $\mathrm{RH}, 49 \%$ minimum RH). Every tray, including the control tray, was partially filled with tap water as described previously (19).

After 4 weeks in the growth chamber, the severity of aerial and root symptoms was assessed for each plant on a 0 to 4 scale, according to the percentage of foliage with yellowing or necrosis or root necrosis $(0=0 \%, 1=1-33 \%, 2=34-66 \%$, $3=67-99 \%, 4=$ dead plant) (19). Analysis of variance was performed for aerial and root symptom severity, and mean values were compared by the Fisher's protected LSD test (20). In addition, orthogonal comparisons were made between the mean severity values of the olive isolates and isolates from other hosts.

A second pathogenicity test was carried out using chickpea (Cicer arietinum) as a host. Cultivar ILC-3279 was used because of its high susceptibility to $P$. ciceris ( $P$. megasperma sl) root rot (18). Three Phytophthora isolates were chosen: two from olive trees (PO4 and PO8) and one from chickpea (PM033). Inoculum preparation, climatic conditions, waterlogging, and statistical analysis of the data were as described above. Two-liter plastic pots were filled with infested or control soil (three pots per isolate tested plus three control pots), and 10 pregerminated chickpea seeds were placed in each pot. When the seedlings emerged, the plastic trays were partially filled with tap water.

At the end of each test, segments from inoculated and control roots were plated on PARPH (Cornmeal agar + Pimaricin, Ampicilin, Rifampicin, Pentachloronitrobencene, Hymexazol) medium (14) for reisolation of the pathogen. Both tests were conducted twice. 


\section{RESULTS}

Colony morphologies and growth rates. The colony morphology assessments on CA medium separated the isolates into two groups, A and B (Table 1). Group A comprised 36 of the 52 isolates examined. These isolates produced white, flat colonies, with a powdery appearance when oospores were abundant. Some isolates isolates of group B produced white colonies with a clear petaloid (rosette) pattern. On CMA medium, none of the isolates or groups showed differences in colony morphology.

Growth rates taken at 4 to 6 days were the most representative for all isolates. No differences were observed in growth rates of the isolates on CA or CMA. To express growth rate versus temperature, a third degree polynomic model was selected: $y=$ $a^{*} T^{3}+b^{*} T^{2}+c^{*} T$, with $y$ being the growth rate, $T=$ temperature and $a, b, c$, the regression constants. Two different developed slight petaloid patterns. The 16

growth patterns, corresponding to groups A and B were obtained (Fig. 1). The optimum growth temperature estimated for the group A isolates was approximately $21^{\circ} \mathrm{C}$ (Table 2). This group grew slowly at $30^{\circ} \mathrm{C}$. The optimum growth temperature for group B isolates was approximately $26^{\circ} \mathrm{C}$ (Table 2). This group exhibited fast growth at $30^{\circ} \mathrm{C}$. No growth was recorded for any isolate at $35^{\circ} \mathrm{C}$.

Morphological characterization. All 12 group $\mathrm{A}$ isolates produced gametangia in single culture. Five of the 13 group B isolates examined produced gametangia slowly and sporadically on CA (Table 4). Isolate PO34 did not produce gametangia on CA, but did do so in single culture in liquid non-sterile soil extract. (In this exceptional case, measurements of gametangial structures were made from this medium). Two other group B isolates, PO8 and PO39, mated with the A2 tester of $P$. drechsleri. The other five isolates remained sterile (Table 4).
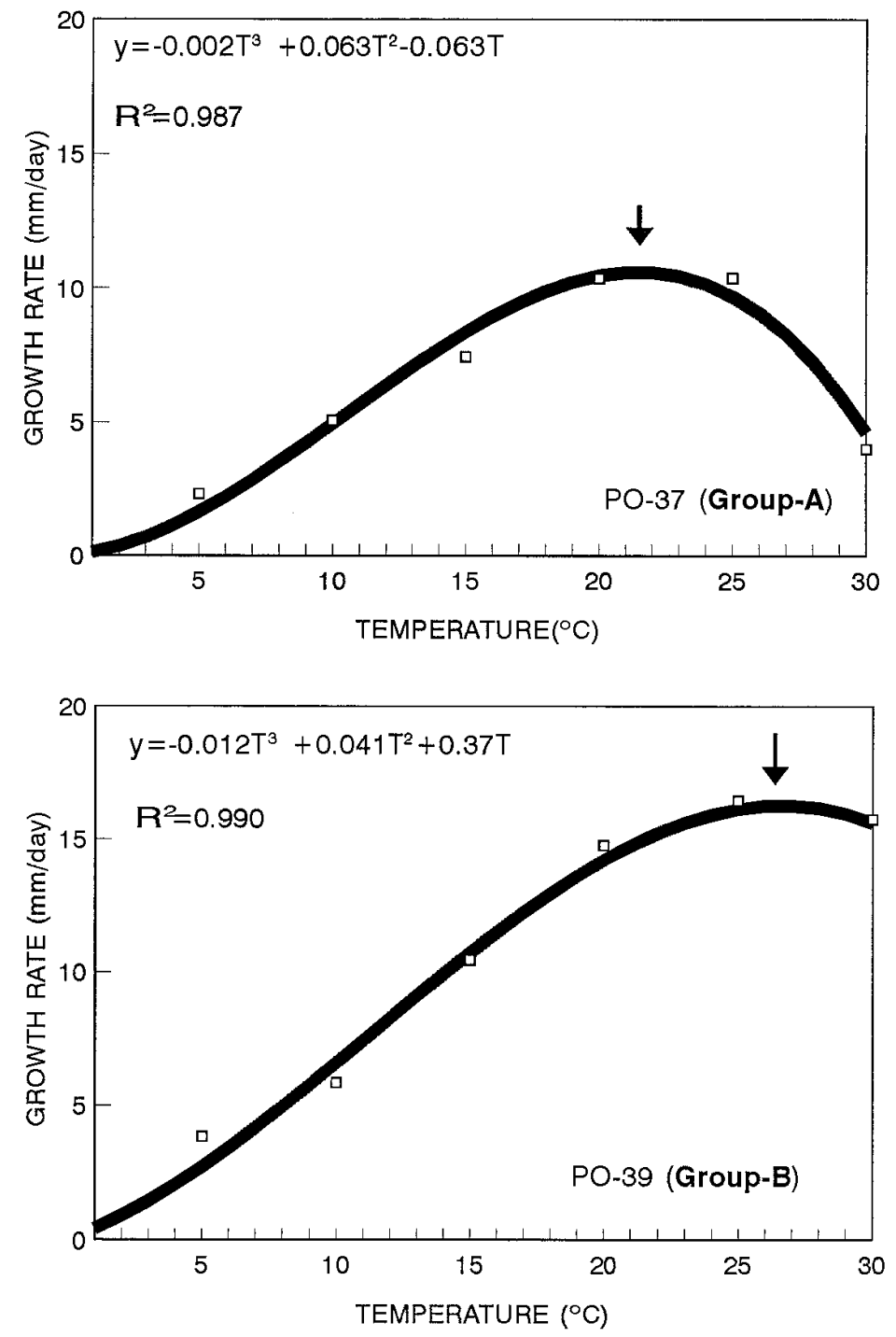

Fig. 1. Estimated growth rate curves for the Group A isolate PO37 and the Group B isolate PO39. Points represent actual measurements. Arrows mark the estimated optimal temperatures (21.4 and $26.7^{\circ} \mathrm{C}$, respectively). Within each group, the isolates exhibited similar growth patterns.
The mean dimensions of the oogonia, oospores, and antheridia varied significantly $(P \leq 0.05)$ among all the isolates, and among the isolates of each group (Tables 3 and 4). Asexual structures were morphologically similar in groups A and B, but those of group B isolates were larger than those of group A (Tables 5 and 6). Table 7 summarizes the morphological characteristics of each group of isolates. Characteristics of Group A are in a good agreement with the description of $P$. megasperma "BHR-type" or sensu stricto (12). Isolate P03 was confirmed to be $P$. megasperma sensu stricto in a sequence analysis of its ITS rDNA region (7, C. M. Brasier and D. L. Cooke, unpublished data). In terms of colony pattern, sporangial type and temperature-growth relationships, group B isolates conformed closely to the "O-group" taxon of Brasier et al. (5). Furthermore, the sequences of the ITS rDNA regions of isolates PO15 and PO8 confirmed their alignment with this taxon (7, C. M. Brasier and D. L. Cooke, unpublished data).

Pathogenicity tests. All plants inoculated with A and B group isolates from olive showed extensive root necrosis accompanied by moderate to severe crown symptoms (Fig. 2). In contrast, those inoculated with Phytophthora isolates from other hosts had only a low level of root rot, limited crown symptoms, and exhibited growth of new rootlets. Orthogonal comparisons showed these isolates were significantly less aggressive than the olive isolates on olive cuttings (Fig. 2). No differences in aggressiveness were detected between isolates from morphological

Table 2. Optimum growth temperature estimated for Phytophthora isolates in carrot agar medium

\begin{tabular}{|c|c|c|}
\hline $\begin{array}{l}\text { Isolate } \\
\text { group }\end{array}$ & Isolate & $\begin{array}{l}\text { Optimum growth } \\
\text { temperature }\left({ }^{\circ} \mathrm{C}\right)\end{array}$ \\
\hline A & PO3 & 21.3 \\
\hline A & PO4 & 20.5 \\
\hline A & PO10 & 21.7 \\
\hline A & PO12 & 21.4 \\
\hline A & PO20 & 20.1 \\
\hline A & PO26 & 21.5 \\
\hline A & PO37 & 21.4 \\
\hline A & PO40 & 21.8 \\
\hline A & PO42 & 23.7 \\
\hline A & PO53 & 22.7 \\
\hline A & PO56 & 20.6 \\
\hline A & PO63 & 20.3 \\
\hline B & PO8 & $>30$ \\
\hline B & PO15 & 25.8 \\
\hline B & PO16 & 25.8 \\
\hline B & PO27 & 25.3 \\
\hline B & PO28 & 25.3 \\
\hline B & PO34 & 26.1 \\
\hline B & PO35 & 24.9 \\
\hline B & PO38 & 25.4 \\
\hline B & PO39 & 26.7 \\
\hline B & PO47 & 25.3 \\
\hline B & PO50 & 24.2 \\
\hline B & PO55 & 27.0 \\
\hline B & PO62 & 24.7 \\
\hline
\end{tabular}


groups A and B. In the control plants, there was a low level of root necrosis, likely due to root asphyxiation, abundant production of new rootlets and no crown symptoms.

In the pathogenicity tests on chickpea, only the $P$. ciceris isolate from chickpea (PM033) produced extensive root necrosis and a total collapse of the aerial part of the plant. Control plants and plants inoculated with other isolates of Phytophthora, including the isolates from olive, did not show any symptoms of disease.

In all cases, the inoculated Phytophthora species were consistently recovered from olive or chickpea necrotic roots.

\section{DISCUSSION}

Fifty-two Phytophthora isolates associated with root rot and sudden death of young olive trees in southern Spain (19) were characterized. On the basis of their morphological and physiological properties, they were assigned to two distinct groups, $\mathrm{A}$ and $\mathrm{B}$, representing $66 \%$ and $33 \%$ of the isolates respectively.

All the group A isolates conformed to $P$. megasperma sensu stricto (13); i.e., the

Table 5. Characteristics of sporangia of Group A Phytophthora isolates in soil extract

\begin{tabular}{lcccc}
\hline Isolate & $\begin{array}{c}\text { Sporangial length } \\
(\boldsymbol{L})(\boldsymbol{\mu m})\end{array}$ & $\begin{array}{c}\text { Sporangial breadth } \\
(\boldsymbol{B})(\boldsymbol{\mu m})\end{array}$ & Pore width $(\boldsymbol{\mu m})$ & $\boldsymbol{L} / \boldsymbol{B}$ \\
\hline PO-3 & $50.0 \pm 4.9 \mathrm{y}$ & $36.8 \pm 3.5$ & $11.2 \pm 1.5$ & $1.4 \pm 0.2$ \\
PO-4 & $36.0 \pm 4.9$ & $23.7 \pm 3.8$ & $8.5 \pm 1.4$ & $1.5 \pm 0.2$ \\
PO-10 & $43.3 \pm 4.9$ & $29.8 \pm 3.7$ & $8.5 \pm 1.7$ & $1.5 \pm 0.2$ \\
PO-12 & $34.7 \pm 12.7$ & $22.5 \pm 10$ & $8.7 \pm 1.9$ & $1.6 \pm 0.3$ \\
PO-20 & $46.3 \pm 8.0$ & $28.6 \pm 4.4$ & $10.1 \pm 0.6$ & $1.6 \pm 0.2$ \\
PO-26 & $59.8 \pm 4.8$ & $43.8 \pm 4.6$ & $11.5 \pm 1.6$ & $1.4 \pm 0.1$ \\
PO-37 & $44.0 \pm 4.5$ & $30.7 \pm 4.2$ & $9.8 \pm 0.7$ & $1.4 \pm 0.1$ \\
PO-40 & $38.0 \pm 4.6$ & $24.5 \pm 3.4$ & $7.6 \pm 1.9$ & $1.7 \pm 0.2$ \\
PO-42 & $28.2 \pm 7.2$ & $19.1 \pm 5.3$ & $7.5 \pm 2.1$ & $1.5 \pm 0.2$ \\
PO-53 & $34.0 \pm 5.3$ & $22.8 \pm 6.8$ & $5.9 \pm 1.3$ & $1.6 \pm 0.3$ \\
PO-56 & $36.4 \pm 4.7$ & $22.3 \pm 2.6$ & $8.8 \pm 2.1$ & $1.6 \pm 0.3$ \\
PO-63 & $40.7 \pm 6.2$ & $24.9 \pm 5.4$ & $9.6 \pm 1.2$ & $1.7 \pm 0.2$ \\
LSD & 3.90 & 2.97 & 1.01 & 0.12 \\
\hline
\end{tabular}

${ }^{y}$ Mean values (in $\mu \mathrm{m}$ ) of 25 structures measured \pm standard error.

${ }^{\mathrm{z}}$ Least significant difference according to Fisher's protected test $(P=0.05)(20)$. broad host range (BHR) biological species group of Hansen et al. (12). They were also confirmed to be $P$. megasperma based on molecular analysis of the ITS regions.

Table 3. Characteristics of sexual structures of Group A Phytophthora isolates in single culture

\begin{tabular}{lccccr}
\hline & \multicolumn{5}{c}{ Mean and SE $(\boldsymbol{\mu m})$} \\
Isolate & Oogonium diameter & Oospore diameter & Oospore wall thickness & Antheridium length & Amphigynous antheridia $(\%)$ \\
\hline PO-3 & $44.4 \pm 4.0^{y}$ & $40.0 \pm 3.8$ & $7.8 \pm 1.5$ & $13.9 \pm 1.9$ & 6 \\
PO-4 & $37.3 \pm 3.9$ & $30.0 \pm 4.6$ & $4.3 \pm 1.4$ & $12.4 \pm 2.6$ & 12 \\
PO-10 & $41.4 \pm 2.2$ & $36.5 \pm 2.3$ & $6.9 \pm 1.7$ & $15.3 \pm 3.3$ & 65 \\
PO-12 & $44.7 \pm 4.2$ & $39.2 \pm 5.1$ & $3.7 \pm 1.1$ & $13.4 \pm 1.4$ & 20 \\
PO-20 & $41.5 \pm 3.0$ & $36.6 \pm 3.0$ & $4.9 \pm 0.9$ & $10.4 \pm 1.9$ & 17 \\
PO-26 & $39.1 \pm 4.4$ & $33.7 \pm 4.5$ & $4.2 \pm 1.1$ & $12.5 \pm 2.4$ & 1.8 \\
PO-37 & $42.0 \pm 3.7$ & $36.6 \pm 3.3$ & $4.7 \pm 0.8$ & $12.8 \pm 2.6$ & 12 \\
PO-40 & $39.5 \pm 2.9$ & $34.6 \pm 2.9$ & $4.2 \pm 1.1$ & $13.2 \pm 2.0$ & 16 \\
PO-42 & $40.9 \pm 3.0$ & $36.2 \pm 1.5$ & $4.9 \pm 0.4$ & $14.0 \pm 2.0$ & 0 \\
PO-53 & $39.4 \pm 2.9$ & $35.5 \pm 3.0$ & $4.6 \pm 0.9$ & 20 \\
PO-56 & $40.9 \pm 2.7$ & $35.2 \pm 2.5$ & $4.8 \pm 0.7$ & $14.7 \pm 2.6$ & 0.88 \\
PO-63 & $45.2 \pm 3.3$ & $41.7 \pm 3.2$ & $4.7 \pm 0.8$ & 0.60 \\
LSD $^{\mathbf{z}}$ & 1.90 & 1.92 & &
\end{tabular}

y Mean values (in $\mu \mathrm{m}$ ) of 25 structures measured \pm standard error.

${ }^{\mathrm{z}}$ Least significant difference according to Fisher's protected test $(P=0.05)(20)$.

Table 4. Characteristics of sexual structures of Group B Phytophthora isolates in single culture

\begin{tabular}{|c|c|c|c|c|c|c|}
\hline \multirow[b]{2}{*}{ Isolate } & \multicolumn{4}{|c|}{ Mean and SE $(\mu \mathrm{m})$} & \multirow[b]{2}{*}{$\begin{array}{c}\text { Amphigynous } \\
\text { antheridia (\%) }\end{array}$} & \multirow[b]{2}{*}{$\begin{array}{l}\text { Sexual compatibility type in pair- } \\
\text { ings with } \mathrm{A} 1 \text { or } \mathrm{A} 2 \text { P. drechsleri }\end{array}$} \\
\hline & $\begin{array}{c}\text { Oogonium } \\
\text { diameter }\end{array}$ & $\begin{array}{l}\text { Oospore } \\
\text { diameter }\end{array}$ & $\begin{array}{c}\text { Oospore } \\
\text { wall thickness }\end{array}$ & $\begin{array}{l}\text { Antheridium } \\
\text { length }\end{array}$ & & \\
\hline \multicolumn{7}{|c|}{ Weakly self fertile } \\
\hline PO- 15 & $34.7 \pm 7.5^{\mathrm{u}}$ & $31.4 \pm 7.4$ & $7.2 \pm 3.0$ & $15.8 \pm 2.6$ & 100 & $n \mathrm{t}^{\mathrm{x}}$ \\
\hline PO-27 & $41.4 \pm 4.6$ & $37.3 \pm 3.7$ & $5.0 \pm 1.3$ & $17.3 \pm 3.6$ & 100 & $\mathrm{nt}$ \\
\hline PO-28 & $43.2 \pm 5.2$ & $38.1 \pm 4.7$ & $5.1 \pm 1.3$ & $15.1 \pm 2.5$ & 100 & $\mathrm{nt}$ \\
\hline PO-47 & $40.5 \pm 4.0$ & $35.9 \pm 3.2$ & $5.0 \pm 0.0$ & $18.4 \pm 2.2$ & 100 & $\mathrm{nt}$ \\
\hline PO-50 & $43.4 \pm 4.7$ & $38.2 \pm 4.1$ & $5.3 \pm 1.4$ & $17.0 \pm 3.3$ & 100 & $\mathrm{nt}$ \\
\hline $\mathrm{PO}-34^{\mathrm{v}}$ & $37.1 \pm 3.0$ & $33.1 \pm 3.1$ & $4.9 \pm 0.5$ & $15.6 \pm 2.3$ & 73 & A1 \\
\hline \multicolumn{7}{|c|}{ Self sterile } \\
\hline PO-8 & $\ldots^{\mathrm{z}}$ & $\ldots$ & $\ldots$ & $\ldots$ & $\ldots$ & A1 \\
\hline PO-16 & $\ldots$ & $\ldots$ & $\ldots$ & $\ldots$ & $\ldots$ & neutral ${ }^{\mathrm{y}}$ \\
\hline PO-35 & $\ldots$ & $\ldots$ & $\ldots$ & $\ldots$ & $\ldots$ & neutral \\
\hline PO-38 & $\ldots$ & $\ldots$ & $\ldots$ & $\ldots$ & $\ldots$ & neutral \\
\hline PO-39 & $\ldots$ & $\ldots$ & $\ldots$ & $\ldots$ & $\ldots$ & A1 \\
\hline PO-55 & $\ldots$ & $\ldots$ & $\ldots$ & $\ldots$ & $\ldots$ & neutral \\
\hline PO-62 & $\ldots$ & 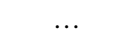 & & & $\ldots$ & neutral \\
\hline LSD $^{w}$ & 2.80 & 2.57 & 0.86 & 1.57 & & \\
\hline
\end{tabular}

u Mean values (in $\mu \mathrm{m}$ ) of 25 structures measured \pm standard error.

${ }^{\mathrm{v}}$ Sexual structures in single cultures of PO34 observed only in soil extract.

${ }^{\mathrm{w}}$ Least significant difference according to Fisher's protected test $(P=0.05)(20)$.

${ }^{\mathrm{x}} \mathrm{nt}=$ not tested.

y No oogonia produced in pairings with $P$. drechsleri.

${ }^{\mathrm{z}}$ Gametangia not produced in single culture. 
Therefore, $P$. megasperma appears to be the most common species associated with olive root rot in Spain. Kouyeas and Chitzanidis (15) described a single Phytophthora isolate from roots of an olive tree in Greece with similar morphological characteristics to our group A isolates. They also attributed this isolate to $P$. megasperma. Optimum growth temperatures reported by various authors for $P$. megasperma ss isolates from different hosts (excluding the 'AC' and 'DF' taxa of Hansen et al. (12), which are probably unique Phytophthora species) range from 20 to $25^{\circ} \mathrm{C}(10,13)$. The optimum temperature for growth of all 32 olive isolates of $P$. megasperma in the present study was also 20 to $25^{\circ} \mathrm{C}$, with a rapid decline in growth rate above $25^{\circ} \mathrm{C}$.

Group B isolates were distinct from the $P$. megasperma isolates. Their colonies exhibited a distinctive rosette growth pattern on CA, whereas those of P. megasperma were uniform and flat. They had a higher optimum temperature for growth and were still able to grow rapidly at $30^{\circ} \mathrm{C}$.

Table 6. Characteristics of sporangia of Group B Phytophthora isolates in soil extract

\begin{tabular}{lcccc}
\hline Isolate & $\begin{array}{c}\text { Sporangial length } \\
(\boldsymbol{L})(\boldsymbol{\mu m})\end{array}$ & $\begin{array}{c}\text { Sporangial breadth } \\
(\boldsymbol{B})(\boldsymbol{\mu m})\end{array}$ & Pore width $(\boldsymbol{\mu m})$ & $\boldsymbol{L} / \boldsymbol{B}$ \\
\hline PO-8 & $78.2 \pm 4.6^{\mathrm{x}}$ & $62.8 \pm 5.4$ & $16.9 \pm 2.8$ & $1.2 \pm 0.1$ \\
PO-15 & $\ldots \mathrm{y}$ & $\ldots$ & $\ldots$ & $\ldots$ \\
PO-16 & $55.0 \pm 5.8$ & $41.1 \pm 5.1$ & $10.2 \pm 1.1$ & $1.3 \pm 0.1$ \\
PO-27 & $61.1 \pm 7.8$ & $44.1 \pm 7.9$ & $12.7 \pm 1.9$ & $1.4 \pm 0.1$ \\
PO-28 & $\ldots$ & $40.0 \pm 5.5$ & $\ldots$ & $\ldots$ \\
PO-34 & $54.7 \pm 6.5$ & $40.5 \pm 6.7$ & $11.2 \pm 1.7$ & $1.4 \pm 0.1$ \\
PO-35 & $55.8 \pm 6.7$ & $66.5 \pm 5.1$ & $9.9 \pm 0.6$ & $1.4 \pm 0.2$ \\
PO-38 & $85.6 \pm 7.5$ & $42.4 \pm 7.3$ & $12.6 \pm 2.0$ & $1.3 \pm 0.1$ \\
PO-39 & $62.9 \pm 7.5$ & $\ldots$ & $14.5 \pm 2.1$ & $1.5 \pm 0.1$ \\
PO-47 & $\ldots$ & $\ldots$ & $\ldots$ & $\ldots$ \\
PO-50 & $\ldots$ & $41.9 \pm 7.4$ & $11.0 \pm 1.3$ & $1.5 \pm 0.1$ \\
PO-55 & $62.6 \pm 9.1$ & $50.3 \pm 8.2$ & $10.4 \pm 1.0$ & $1.3 \pm 0.1$ \\
PO-62 & $64.9 \pm 7.9$ & 4.12 & 1.09 & 0.08 \\
LSD & 4.48 & $\ldots$ & & $\ldots$ \\
\hline
\end{tabular}

${ }^{\mathrm{x}}$ Mean values (in $\mu \mathrm{m}$ ) of 25 structures measured \pm standard error.

${ }^{y}$ No sporangial production.

${ }^{\mathrm{z}}$ Least significant difference according to Fisher's protected test $(P=0.05)(20)$.

They produced almost exclusively amphigynous antheridia. In addition, group B isolates were either entirely self-sterile, self-sterile A1s or weakly self-fertile. Therefore, they have a different breeding system from the homothallic P. megasperma. A separate study indicates they are fundamentally outcrossing, heterothallic but with a degree of sporadic self-fertility (C. M. Brasier and M. E. SánchezHernández, unpublished data). Their selffertility may be due to the presence of an extra chromosome carrying the opposite mating type $(2,16)$.

The colony types, sporangial types and temperature-growth relationships of the Bgroup isolates, including their rapid growth at $30^{\circ} \mathrm{C}$, conform closely to those of the unusual 'O-group' taxon described by Brasier et al. (5). They also conformed to the 'O-group' in their ITS sequence (7). In a separate study, involving O-group isolates from a wide range of hosts, both $\mathrm{A} 1$ and A2 mating types have been identified (C. M. Brasier and M. E. Sánchez-Hernández, unpublished data). Because of its unique morphogenetic and behavioural characteristics, including a unique gametangial morphology, the 'O-group' taxon will be designated elsewhere as a new species.

Pathogenicity tests showed both the $P$. megasperma and 'O-group' isolates were highly aggressive pathogens on roots of young olive trees. In contrast, control

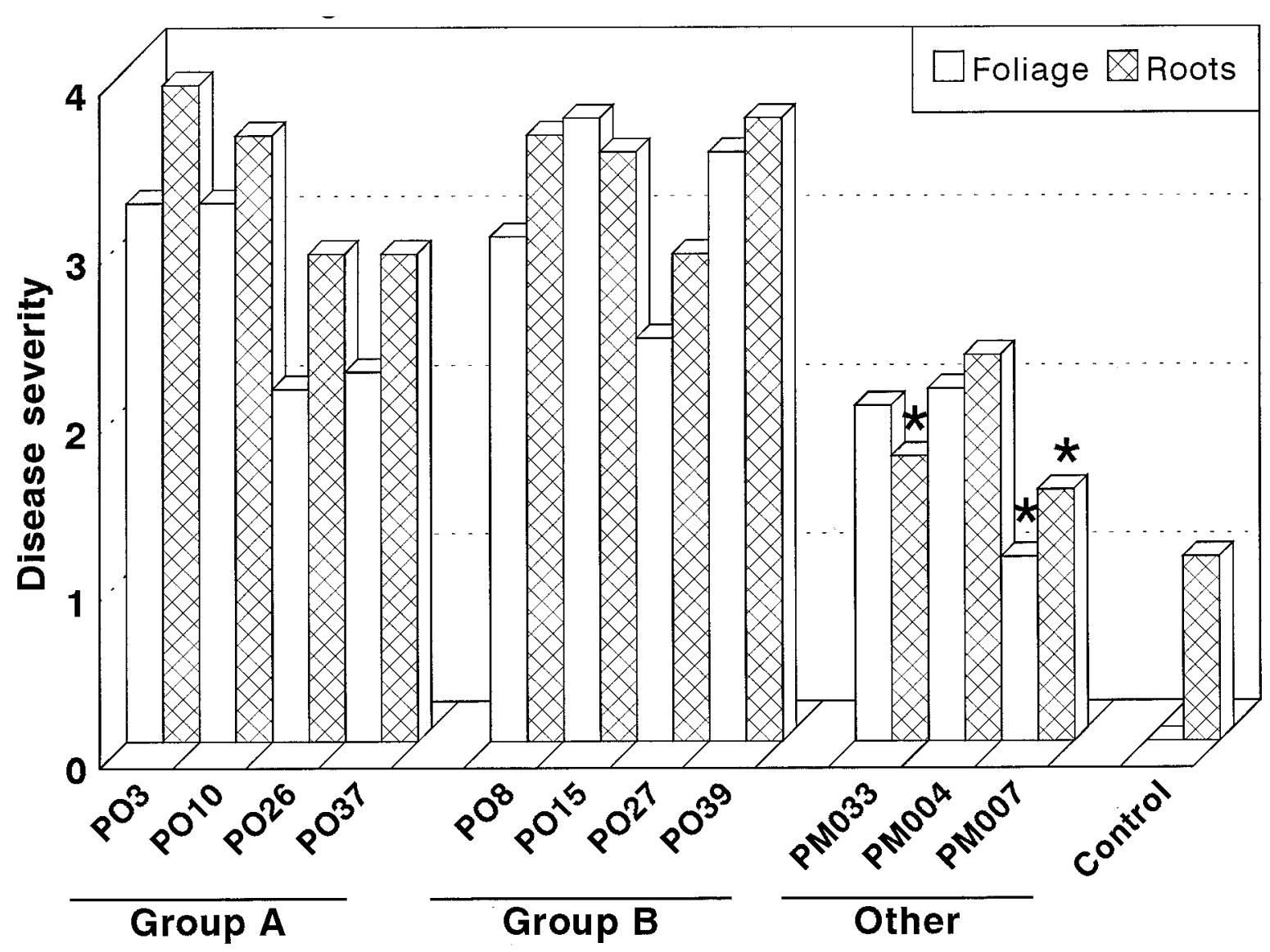

Fig. 2. Pathogenicity of Phytophthora isolates in olive tree. Scale of disease severity: $0=$ no symptoms, $4=100 \%$ necrotic tissue. Asterisks mark the mean values not significantly different from the control (least significant difference, $P \leq 0.05$ ). 
Table 7. Morphological characteristics of Phytophthora spp. Group A and B

\begin{tabular}{|c|c|c|c|}
\hline \multirow[b]{2}{*}{ Breeding system } & & \multirow{2}{*}{$\begin{array}{c}\text { Group A } \\
\text { Homothallic }^{\mathrm{x}}\end{array}$} & \multirow{2}{*}{$\begin{array}{c}\text { Group B } \\
\text { Sterile or A1/A2 heterothallic } \mathrm{y}\end{array}$} \\
\hline & & & \\
\hline \multirow[t]{2}{*}{ Oogonia } & Smooth & + & + \\
\hline & Mean diam $(\mu \mathrm{m})$ & $41.7 \pm 4.1^{\mathrm{z}}$ & $40.1 \pm 5.7$ \\
\hline \multirow{3}{*}{ Oospores } & Aplerotic & + & + \\
\hline & Thick-walled & + & + \\
\hline & Mean diam $(\mu \mathrm{m})$ & $36.9 \pm 4.4$ & $35.5 \pm 5.0$ \\
\hline \multirow[t]{3}{*}{ Antheridia } & Paragynous & + & $(+)$ \\
\hline & Amphigynous & $(+)$ & + \\
\hline & Mean length $(\mu \mathrm{m})$ & $12.9 \pm 2.6$ & $16.8 \pm 3.3$ \\
\hline Sporangiophores & Sympodial branching & + & + \\
\hline \multirow[t]{6}{*}{ Sporangia } & Non papillate & + & + \\
\hline & Persistent & + & + \\
\hline & Proliferating & + & + \\
\hline & Shape & ovoid-obpyriform & ovoid \\
\hline & Mean length $(\mu \mathrm{m})$ & $41.6 \pm 10.2$ & $64.2 \pm 12.3$ \\
\hline & Mean breadth $(\mu \mathrm{m})$ & $27.9 \pm 8.3$ & $47.4 \pm 11.5$ \\
\hline
\end{tabular}

$\mathrm{x}+=$ Character always present $;+=$ Character usually present; $(+)=$ Character sometimes present y Some heterothallic isolates weakly self-fertile.

${ }^{\mathrm{z}}$ Mean values (in $\left.\mu \mathrm{m}\right) \pm$ standard error.

Phytophthora species from other hosts, including a $P$. megasperma isolate from peach, were either weakly or nonpathogenic to olive. Moreover, the two olive isolate types were non-pathogenic to chickpea plants, while the chickpea isolate, obtained from the same area and soil type that olive isolates (19), was highly agressive to chickpea. P. megasperma is viewed as having a broad host range, including an ability to attack many tree genera (e.g. 3, $10,12)$. Whether the olive isolates of this species exhibit a degree of specificity towards their host needs to be investigated through additional pathogenicity tests using isolates from a wider range of hosts.

The temperature-growth requirements of $P$. megasperma and the O-group are distinct, the former being a moderate and the latter a high temperature organism. Some $\mathrm{O}$-group isolates grow well even at $37^{\circ} \mathrm{C}$ (5). Provided the soil has a suitably high water content for infection, the two species may be at their most active in different seasons. This might represent a low level of competition between the two taxa for infection of olive roots.

Traditionally, olive trees are considered highly sensitive to "root asphyxiation" following flooding (1). However, we have shown previously that higher soil moisture levels result in higher levels of root rot (19). Based on this study, what was previously considered as "root asphyxiation" should more properly be regarded as Phytophthora root-rot. Such new perspectives, together with a growing understanding of the ecology and variability of the patho- gens involved, should help to establish better management strategies for the control of the disease. It seems reasonable to propose that susceptibility to Phytophthora root rot may have limited the natural ecological distribution of olive trees (17). Certainly, it is clear that they should not be planted in conditions where flooding occurs or in areas with poor drainage.

\section{ACKNOWLEDGMENTS}

We thank F. Luque for her skillful technical assistance. This research work was supported by the project AGF96-1082 from the Comisión Interministerial de Ciencia y Tecnología (Spain).

\section{LITERATURE CITED}

1. Barranco, D., Fernández-Escobar, R., and Rallo, L., eds. 1999. El cultivo del olivo. Mundi Prensa-Junta de Andalucía, Madrid.

2. Brasier, C. M. 1992. Evolutionary biology of Phytophthora. Part I: Genetic system, sexuality and the generation of variation. Annu. Rev. Phytopathol. 30:153-171.

3. Brasier, C. M. 2000. The role of Phytophthora pathogens in forests and semi-natural communities in Europe and Africa. Pages 6-13 in: Proceedings of the 1st IUFRO Working Group on Phytophthora diseases of trees, Oregon. August 29-Sept. 3 1999. E. M. Hansen and W. Sutton, eds.

4. Brasier, C. M., and Griffin, M. J. 1979. The taxonomy of Phytophthora palmivora on cocoa. Trans. Br. Mycol. Soc. 72:111-143.

5. Brasier, C. M., Hamm, P. B., and Hansen, E. M. 1993. Cultural characters, protein patterns and unusual mating behaviour of Phytophthora gonapodyides isolates from Britain and North America. Mycol. Res. 97:1287-1298.

6. Browne, G. T., and Mircetich, S. M. 1988. Effects of flood duration of the development of Phytophthora root and crown rots of apple. Phytopathology 78: 846-851.

7. Cooke, D. G. L., Drenthe, A., Duncan, J. M.,
Wagels, G., and Brasier, C. M. 2000. A molecular phylogeny of Phytophthora and related oomycetes. Fungal Gen. Biol. 30:17-32.

8. Dhingra, O. D., and Sinclair, J. B. 1995. Basic plant pathology methods. CRC Press, Boca Raton, FL.

9. Draper, N. R., and Smith, H. 1981. Applied Regression Analysis. 2nd ed. John Wiley and Sons, New York.

10. Erwin, D. C., and Ribeiro, O. K. 1996. Phytophthora diseases worldwide. APS Press, St. Paul, MN.

11. Farr, D. F., Bills, G. F., Chamuris, G. P., and Rossman, A. Y. 1989. Fungi on plants and plant products in the United States. APS Press, St. Paul, MN.

12. Hansen, E. M., Brasier, C. M., Shaw, D. S., and Hamm, P. B. 1986. The taxonomic structure of Phytophthora megasperma. Evidence for emerging biological species groups. Trans. Br. Mycol. Soc. 87:557-573.

13. Hansen, E. M., and Maxwell, D. P. 1991. Species of Phytophthora megasperma complex. Mycologia 83: 376-381.

14. Jeffers, N. S., and Martin, J. B. 1986. Comparison of two media selective for Phytophthora and Pythium species. Plant Dis. 70:1038-1043.

15. Kouyeas, H., and Chitzanidis, A. 1968. Notes on Greek species of Phytophthora. Ann. Inst. Phytopathol. Benaki, N.S. 8:175-192.

16. Mortimer, A. M., Shaw, D. S., and Sansome, E. R. 1977. Genetical studies of secondary homothallism in Phytophthora drechsleri. Arch. Microbiol. 111:255-259.

17. Packer, A., and Clay, K. 2000. Soil patterns and spatial problems of seedling mortality in a temperate tree. Nature 404:278-281.

18. Rodríguez-Tello, A. 1994. La muerte de plántulas de garbanzo causada por Pythium spp. y Phytophthora megasperma en Andalucía: Etiología y control. Ph.D. diss.. ETSIAM, Universidad de Córdoba.

19. Sánchez-Hernández, M. E., Ruiz-Dávila, A. Pérez de Algaba, A., Blanco-López, M. A., and Trapero-Casas, A. 1998. Occurrence and etiology of death of young olive trees in southern Spain. Eur. J. Plant Pathol. 104:347-357.

20. Steel, G. D., and Torrie, J. H. 1985. Bioestadística: Principios y procedimientos. Mc Graw-Hill, Bogotá.

21. Stolzy, L. H., Letey, J., Klotz, L. J., and Labanauskas, C. K. 1965 . Water and aeration as factors in root rot decay of Citrus sinensis. Phytopathology 55:270-275.

22. Teviotdale, B. E. 1994. Diseases of olive Pages 107-109 in Olive production manual. L. Ferguson, G. S. Sibbett, and G. C. Martin, eds. Publication 3353. University of California.

23. Trapero-Casas, A., and Jiménez-Díaz, R. M. 1985. Fungal wilt and root rot diseases of chickpea in southern Spain. Phytopathology 75:1146-1151.

24. Wilcox, W. F., and Mircetich, S. M. 1987 Pathogenicity and relative virulence of seven Phytophthora spp. on Mahaleb and Mazzard cherry. Phytopathology 75: 221-226.

25. Wilhelm, S., and Kaiser, W. J., Georgopoulos, S. G., and Opitz, K. W. 1962. Verticillium wilt of olives in California. Phytopathology 52:32. 